Piotr Pikulski (piotr.pikulski@pk.edu.pl)

(D) https://orcid.org/0000-0002-3268-8079

Maksymilian Szpyt (maksymilianszpyt@gmail.com)

(D) https://orcid.org/0000-0003-4622-7916

Wydział Architektury, Politechnika Krakowska im. Tadeusza Kościuszki

\title{
Megastruktury hybrydowe - alternatywne rozwiązanie przyszłych obiektów użyteczności publicznej o charakterze stadionowym
}

\section{Hybrid megastructures - alternative solutions for prospective public facilities of stadium characteristics}

\section{Streszczenie}

Od XX wieku na całym świecie wzrasta zapotrzebowanie na wielkie areny sportowe. Problem owych budowli polega w główniej mierze na ich sezonowości lub jednorazowości. Brak daleko idącego planu wykorzystania olbrzymich stadionów kończy się często ich niszczeniem, stopniowym popadaniem w ruinę czy po prostu brakiem zwrotu kosztów ich budowy. Na podstawie analizy wybranych obiektów podjęto próbę znalezienia rozwiązania tego problemu.

Słowa kluczowe: megastruktura, budynek hybrydowy, stadiony, obiekty widowiskowe

\section{Abstract}

Worldwide, starting in the 20th century, the demand for grand sport arenas grows. The major problem with such facilities is their seasonality and nonrecurring events. The absence of a far-reaching plan for utilising gigantic stadiums often results in their decay, their gradual decline to ruin or simply a complete lack of the reimbursement of their costs. Based on selected facilities, an attempt to find the solution to this problem has been made.

Keywords: megastructure, hybrid building, stadiums, spectacle facilities 


\section{WSTĘP}

Rozwój cywilizacyjny przynosi nowe możliwości i osiągnięcia w każdej dziedzinie życia, niestety generując przy tym problemy i coraz większe potrzeby społeczeństwa, którym trzeba sprostać. Obecnie wznosi się nowoczesne, lepsze i większe obiekty użyteczności publicznej, mające nie tylko charakter typowych miejsc pracy, ale także służących handlowi, kulturze czy zaspokojeniu potrzeb rozrywki. Budynki przeznaczone do codziennego użytku podlegają ciągłej eksploatacji i tętnią nieustającym życiem. Co jednak, gdy ogromne areny sportowe mające charakter sezonowy, nie są wykorzystywane codziennie lub są budynkami ,jednorazowymi”, a ich dalsze istnienie generuje większe koszty i straty niż zyski i korzyści? Jednym z generatorów takich budowli są światowe imprezy sportowe. Igrzyska olimpijskie lub piłkarskie mistrzostwa wymagają wielkich aren widowiskowych, na których potrzeby są modernizowane stare lub wznoszone nowe, wielkie budowle. Jakie problemy dotykają te obiekty, gdy wydarzenie, na potrzeby którego zostały wybudowane, się zakończy? Opuszczone areny sportowe są mniej interesujące dla użytkowników, a ich gabaryty sprawiają, że tracą one swoją uniwersalność, ceną za wynajem skutecznie odstraszając potencjalnych najemców. Wprawdzie zarządcy obiektów próbują wykorzystywać je do innych funkcji jak koncerty, imprezy społeczne czy inne rodzaje wydarzeń, to jednak nie wszystkie są w stanie być w ciągłym zagospodarowaniu. Dobrym przykładem może być sytuacja dwunastu brazylijskich stadionów po Mistrzostwach Świata w Piłce Nożnej w 2014 roku (Manfred, 2015). Stadiony, niejednokrotnie zrealizowane w środku lasu tropikalnego, po wykorzystaniu w kilku meczach mistrzostw, przy wydaniu ogromnych ilości pieniędzy na ich budowę, stoją nieużywane, niszczejąc, zarastając roślinnością. Igrzyska olimpijskie w Atenach, podczas których projektowano i wznoszono najnowocześniejsze na tamte czasy areny sportowe, dziś straszą jako ruiny z racji braku pieniędzy na opiekę nad nimi. Stadion Pontiac Silverdome, będący miejscem kultowym, z końcem 2017 roku został poddany rozbiórce z powodu braku dalszych perspektyw jego zastosowania ${ }^{1}$. Problem uwidacznia się coraz bardziej wraz z nowymi, wielkimi wydarzeniami sportowymi realizowanymi w różnych zakątkach świata, prowadząc do nadwyrężenia budżetu miast w celu utrzymania obiektu, a ostatecznie do opuszczenia czy rozbiórki budowli (Szpakowska, 2010).

W nin. artykule autorzy skupią się na problemie ponownego wykorzystania tego typu obiektów i analizie możliwości przekształcenia ich w tzw. megastruktury, ze szczególnym naciskiem na problematykę budownictwa mieszkalnego oraz użyteczności publicznej.

1 Na podstawie materiałów zaczerpniętych z: http://www.bryla.pl/bryla/56,85301,16476879,Opuszcz one_stadiony__wyschniete_baseny__Ateny_10_lat.html (dostęp: 6.03.2021). 


\section{METODA BADAWCZA}

W badaniach zastosowano jako metodę badawczą analizę wybranych przykładów nieudanych inwestycji, zapoznano się z historią obiektu oraz okolicznościami i przyczynami jego upadku. Omówione zostały także przykłady już zrealizowanych megastruktur bądź niektóre koncepcje teoretycznych założeń.

\section{ANALIZA PROBLEMU NA PRZYKŁADACH}

Wioski olimpijskie i stadiony będące nietrafnymi inwestycjami można znaleźć na każdym kontynencie. Problemy z nimi związane wydają się mieć bardzo podobne pochodzenie, a ich przeanalizowanie może pozwolić w przyszłości uniknąć zaistnienia podobnych sytuacji, bądź umożliwić bardziej dalekosiężne planowanie ich późniejszych zastosowań.

\subsection{THE PONTIAC SILVERDOME}

Stadion przeznaczony na 82000 miejsc siedzących został otwarty w 1975 roku w Pontiac w stanie Michigan i przez ponad 22 lata był największym tego typu obiektem w Narodowej Lidze Futbolowej. Projekt autorstwa pracowni architektonicznej O’Dell, Hewlett \& Luckenbach oraz lokalnego architekta i urbanisty C. Don Davidsona obejmował obszar 51 hektarów, a koszt budowy na tamte czasy wyniósł niecałe 56 milionów dolarów. Służył nie tylko jako arena sportowa dla wielu dyscyplin, ale pełnił też funkcję estrady koncertowej i miejsca pokazów. Oryginalny dach budowli dzięki któremu zawdzięczał swoją nazwę, był wykonany z paneli z włókna szklanego, powleczonych teflonem, wspartych od wewnątrz ciśnieniem powietrza stadionu. Niestety w roku 1985 silna burza śnieżna dokonała zniszczeń w dachu, prowadząc do remontu obiektu i zastąpienia istniejącego nakrycia również materiałem z włókna szklanego, tym razem podpartego jednak stalowymi dźwigarami. Przy naprawie dokonano kilku ulepszeń w zakresie odwodnienia i impregnacji wodoodpornej. Koszty napraw wyniosły prawie 8 milionów dolarów. Od początku istnienia do 2002 roku stadion gościł na swojej murawie głównie drużynę futbolową Detroit Lions. Wraz z przeniesieniem zespołu przestał on posiadać swojego stałego najemcę i jego wykorzystanie, a co za tym idzie - zarobki drastycznie spadły. Od odejścia drużyny futbolowej miasto Pontiac doświadczyło poważnych problemów finansowych w ciągu kilku lat. Wysokie koszty utrzymania konstrukcji stadionu zmusiły władze miasta do podjęcia kilku nieudanych prób sprzedaży. Pontiac Silverdome ostatecznie trafił na aukcję w 2009 roku, gdzie został sprzedany za 550 tysięcy dolarów. Sytuacja jest o tyle druzgocąca, że rok wcześniej firma United Assurance Company Ltd. składała najwyższą ofertę kupna, oferując 18 milionów dolarów z planami przekształcenia Silverdome w kompleks rozrywkowy w stylu hollywoodzkim. Wtedy jednak odrzucono tę propozycję. Nowy właściciel obiecał przywrócenie stadionu do życia, inwestując w niego 
miliony dolarów, i już od kwietnia 2010 roku miały tu na nowo miejsce różne wydarzenia sportowe. Zarządca rozważał jego renowację i dostosowanie pod drużynę do zawodowej ligi piłkarskiej. Niestety brak ofert najmu oraz uszkodzenia dachu z powodu nadmiernego obciążenia śniegiem na początku 2013 roku ostatecznie przypieczętowały los Silverdome. W 2014 roku pod licytację poddano urządzenia, sprzęt, siedziska, a nawet murawę. Wszystko to sprawiło, że budowla stała się miejscem upadłym i opuszczonym (il. 1-4). Obiekt został przeznaczony do rozbiórki, do tego czasu jego parking, pomimo braku odpowiednich zezwoleń, służył za składowisko samochodów marki Volkswagen z silnikiem Diesla. Z racji tego, że właściciel budynku nie kwapił się do jego rozbiórki, władze miasta na drodze sądowej wyegzekwowały zburzenie stadionu. Ostatecznie został on wysadzony z początkiem grudnia 2017 roku (The Guardian, 2015).
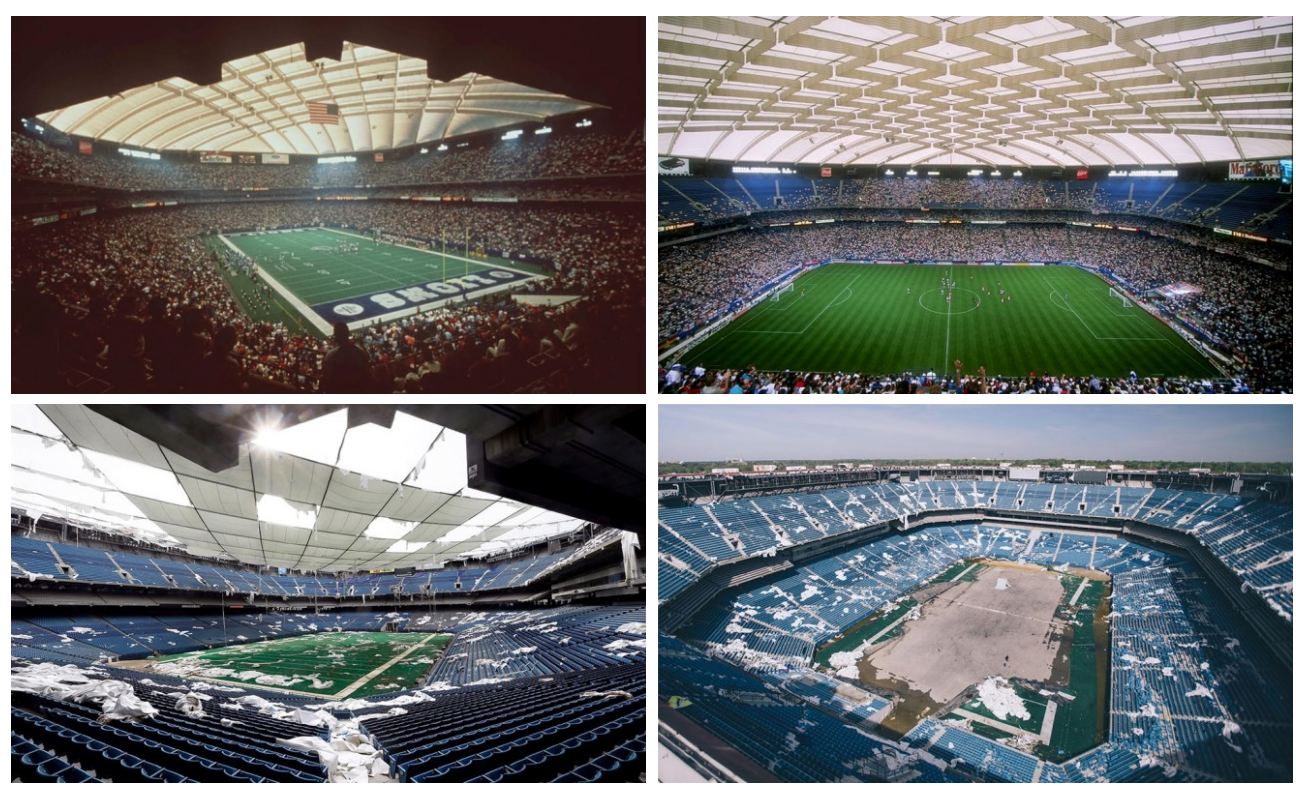

II. 1-4. Zdjęcia ukazujące historię i los stadionu Pontiac Silverdome. Lewy górny róg - rok 1990 podczas gry Detroit Lions. Prawy górny - rok 1994, podczas gry pomiędzy Anglią i Niemcami. Lewy dolny - rok 2014. Prawy dolny - rok 2015 (The Guardian, 2015)

\subsection{STADIONY Z MISTRZOSTW ŚWIATA W PIŁCE NOŻNEJ 2014 W BRAZYLII}

Na Mundial w 2014 roku Brazylia zmodernizowała oraz wybudowała łącznie 12 stadionów, pomimo że Międzynarodowa Federacja Piłki Nożnej wymaga od gospodarzy posiadania od 8 do 10 stadionów w różnych miastach. Największy z nich miał widownię o pojemności blisko 75 tysięcy osób, a najmniejszy 39,5 tysiąca osób. Koszt inwestycji wyniósł ponad 3 biliony 
dolarów. Rok po mistrzostwach ich sytuacja nie była korzystna. Niektóre stadiony cierpiały z powodu chybionej lokalizacji, położone z dala od bardziej zaludnionych obszarów. Na dodatek często miasta nie posiadały wybitnych drużyn piłkarskich będących w stanie przyciągnąć odpowiednią liczbę publiczności, a rozgrywanie lokalnej ligi okazywało się zbyt kosztowne. Co lepsze zespoły, jak Corinthians, nie czerpią zysków z rozgrywanych meczy na swoim stadionie z powodu ciągłego pokrywania kosztów jego budowy. Z kolei najdroższy stadion, czyli Estadio Nacional, kosztujący 550 milionów dolarów, został przekształcony na parking dla autobusów miejskich (il. 5) (Manfred, 2015).

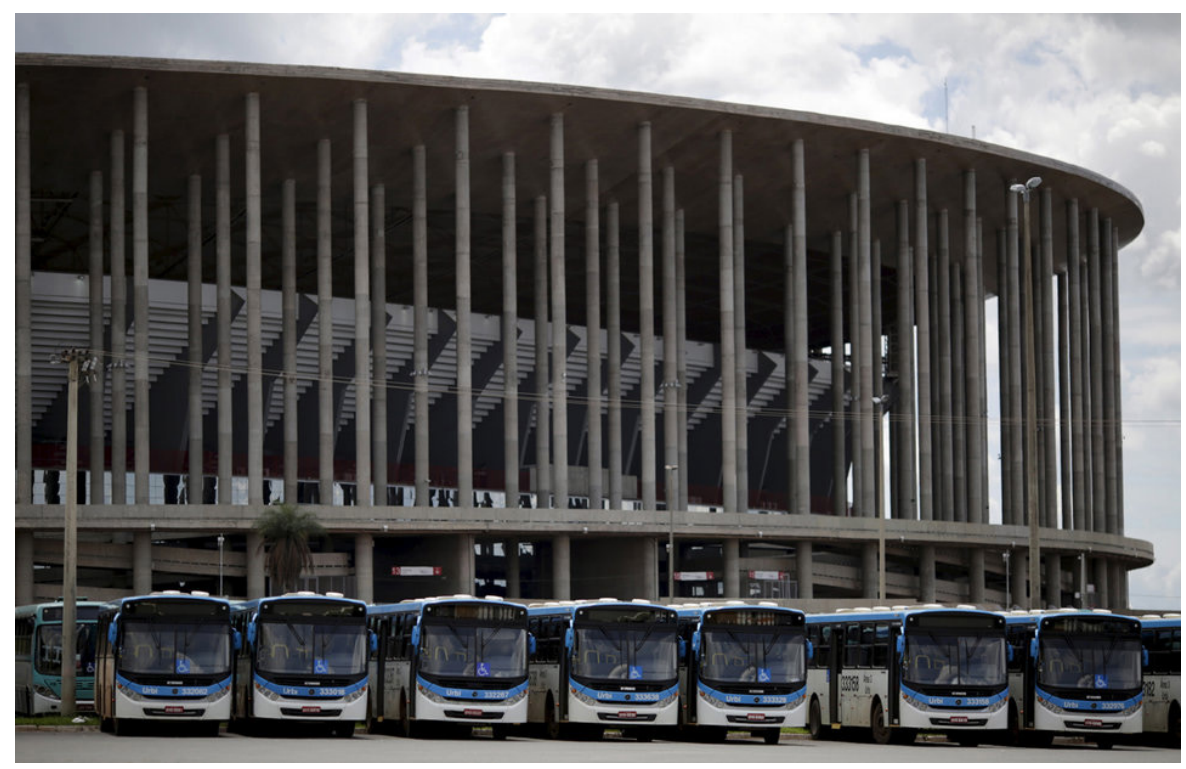

II. 5. Estadio Nacional w Brazylii. Fot. REUTERS/Ueslei Marcelino (Manfred, 2015)

\section{POJĘCIE - HYBRYDY I MEGASTRUKTURY}

\subsection{HYBRYDA}

Kwestia pomysłu zagospodarowania i użytkowania w dłuższej perspektywie czasu wyżej wymienionych obiektów, w celu ich utrzymania bądź ratowania, jest odrębnym problemem. Jednak już na poziomie projektowania można podjąć plan zwiększenia początkowych kosztów inwestycji w celu późniejszych zysków (Gringhuis i Weisner, 2014). Rozwiązaniem dla wyżej omówionych problemów i im podobnych mogą być hybrydy czy inaczej mówiąc obiekty multifunkcjonalne, będące połączeniem paru funkcji w jednym obiekcie. O ile sama koncepcja łączenia wielu funkcji w jednym budynku może nie wydawać się przełomowa, o tyle w ostatnich czasach nabrała ona 
zupełnie nowego wymiaru. Strefa prywatna ze strefą publiczną, dwa odrębne podzbiory wartości zawierające się w jednym zbiorze, jakim jest jedna, zamknięta bryła (Felisberto des Neves, 2012). Powstaje wewnętrzny mutualizm obydwu podzbiorów tworzący budynek funkcjonujący, w pełnym wymiarze czasowym, 24 godziny na dobę (Palej, 2010).

Powstanie terminu „hybryda” w kontekście tkanki urbanistycznej wiąże się w znaczącym stopniu z postępem cywilizacyjnym i podążającym za nim rozwojem miast. Główną cechą hybryd jest wspomniana multifunkcjonalność, łączenie elementów kilku obiektów w jednym, często wskutek przekształceń obiektów zabytkowych lub nadawania im nowych funkcji, dostosowanych do zmieniających się potrzeb użytkowników przestrzeni miejskich (Gyurkovich, 2017). Budynki hybrydowe mogą łączyć zabytkową i współczesną strukturę, mogą być hybrydowymi centrami kultury (łączyć w sobie kilka różnych funkcji kulturalnych) lub być całkowitymi hybrydami funkcjonalnymi (np. łączenie funkcji mieszkalnej i użyteczności publicznej) (Gyurkovich, 2013). Przykładami hybrydowych zespołów kultury są chociażby zlokalizowane w Madrycie Centrum Kultury Conde Duque, będące adaptacją osiemnastowiecznego kompleksu dawnych koszar gwardii królewskiej, oraz Centrum Kultury Matadero, które powstało w wyniku modernizacji i rewitalizacji monumentalnego zespołu rzeźni miejskich z początków XX wieku (Gyurkovich, 2013).

Jednym z celów pojawienia się hybryd w terminologii nowego definiowania tkanki miejskiej jest powrót do jej wielofunkcyjnej, zwartej formy. Same oczekiwania społeczne odnośnie nowych realizacji urbanistycznych również sprzyjają powstawaniu budynków, łączących w sobie wiele, często bardzo zróżnicowanych funkcji. Termin „hybryda” może być stosowany zarówno w odniesieniu do pojedynczych obiektów, jak i fragmentów przestrzeni miejskiej (Gyurkovich, 2016). Na przykładzie urbanistyki Manhattanu Rem Koolhaas zauważa, że dzięki pojęciu hybrydy udało się stworzyć w Nowym Jorku idealny balans, w którym budynki są dialektem pomiędzy dwoma skrajnymi formami współistniejącymi w ich wnętrzu - z jednej strony brutalnie dominują nad miastem, sprawiając wrażenie niedostępnych, z drugiej swoją wytrawnością i prostotą otwierają się na mieszkańców (Koolhaas, 1994).

\subsection{MEGASTRUKTURA}

Czym są megastruktury? W literaturze megastrukturą określa się przeważnie hipotetyczną konstrukcję, która jest wznoszona przez odpowiednio rozwiniętą cywilizację w celu zagwarantowania sobie dodatkowej przestrzeni życiowej, ułatwienia podboju kosmosu, pozyskiwania większej ilości energii lub w innych, wyższych celach². W praktyce, w zależności od skali omawianej tematyki i kontekstu, pojęcie to jest wykorzystywane wraz z przywołaniem pojęcia samowystarczalnej, wielkiej konstrukcji, często zawierającej w sobie mniejsze

$2 \mathrm{Na}$ podstawie definicji zaczerpniętej z: http://encyklopediafantastyki.pl/index.php?title= Megastruktura (dostęp: 20.03.2021). 
jednostki konstrukcyjne. W przypadku architektury określenie to dotyczy koncepcji budynku zawierającego w sobie miasto bądź też mniejszą zabudowę, pozostające we wzajemnej korelacji ${ }^{3}$. Ogólnie ujmując, jest to duży zbiór funkcji zebranych w postaci wielkiej ramy konstrukcyjnej, zawierający mniejsze podzbiory w postaci mniejszych konstrukcji funkcjonalnie współgrających. Już na tym etapie można zauważyć pewną zbieżność pojęć megastruktury i hybrydy na płaszczyźnie teoretycznej (Burazor, 2012).

\section{ANALIZA ROZWIAZZAŃ NA PRZYKŁADACH}

\subsection{MARKTHAL ROTTERDAM, HOLANDIA}

Przykładem funkcjonującego już w Europie obiektu może być Markthal Rotterdam autorstwa pracowni architektonicznej MVRDV. Budynek oprócz funkcji hali targowej kryje w sobie coś jeszcze. Zewnętrzny szkielet obiektu stanowi układ ścian, pomiędzy którymi zaprojektowano apartamenty (il. 6). Wielkością podstawy jest on zbliżony do sportowego boiska do

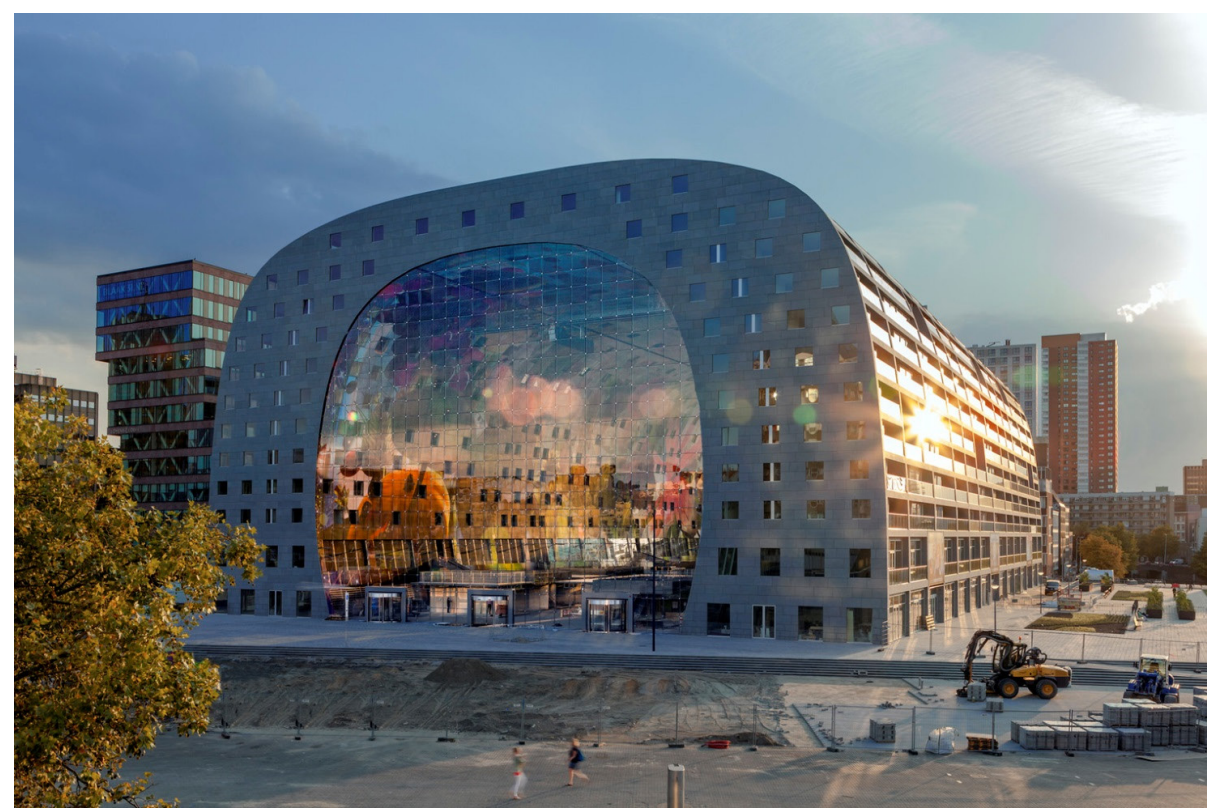

II. 6. Markthal Rotterdam projektu pracowni architektonicznej MVRDV. Fot. D. Scagliola i S. Brakkee (ArchDaily, 2014)

3 Na podstawie definicji zaczerpniętej z: https://en.wikipedia.org/wiki/Megastructure (dostęp: 20.03.2021). 
piłki nożnej. Obiekt posiada cztery kondygnacje, z czego trzy stanowią parking dostępny zarówno dla mieszkańców apartamentów, jak i użytkowników części publicznej. W apartamentach zadbano o ochronę akustyczną, dzięki czemu jakość życia jest tam taka sama, jak w budynku o funkcji mieszkalnej. Budynek sam w sobie jest wielką atrakcją turystyczną miasta i otrzymał wynik bardzo dobry w certyfikacie BREEM dotyczącym zrównoważonej architektury. Obiekt już jest określany jako trwały dodatek do miasta, dostępny 24 godziny na dobę (ArchDaily, 2014).

\subsection{KONCEPCJA ADAPTACJI STADIONÓW NA JEDNOSTKI MIESZKALNE „CASA FUTEBAL" W BRAZYLII}

Kolejnym przykładem możliwego rozwiązania jest koncepcja adaptacji wspomnianych już wcześniej stadionów brazylijskich na jednostki mieszkalne. Pomysł architektów Axela de Stampy i Sylvaina Macaux, pomimo że teoretyczny, zdaje się w pewnym sensie dobrym rozwiązaniem problemu zagospodarowania stadionów oraz deficytu mieszkań dla mieszkańców Brazylii, a konkretniej uboższej części społeczeństwa. Założeniem jest wpasowanie pomiędzy zewnętrzną konstrukcją nośną stadionu około 350 modularnych kontenerów mieszkalnych o różnych powierzchniach użytkowych, pomiędzy 50 a $150 \mathrm{~m}^{2}$. Wizja zakłada finansowanie realizacji oraz utrzymanie mieszkań z pieniędzy uzyskanych z biletów stadionu (Equipo PARQ, 2014). O ile sam pomysł zastosowania funkcji mieszkalnej dla zewnętrznej przestrzeni obiektu jest dobrym krokiem (il. 7), o tyle nietrafny już wydaje się pomysł, aby to stadion, który notabene sam potrzebuje dodatkowego wsparcia finansowego,

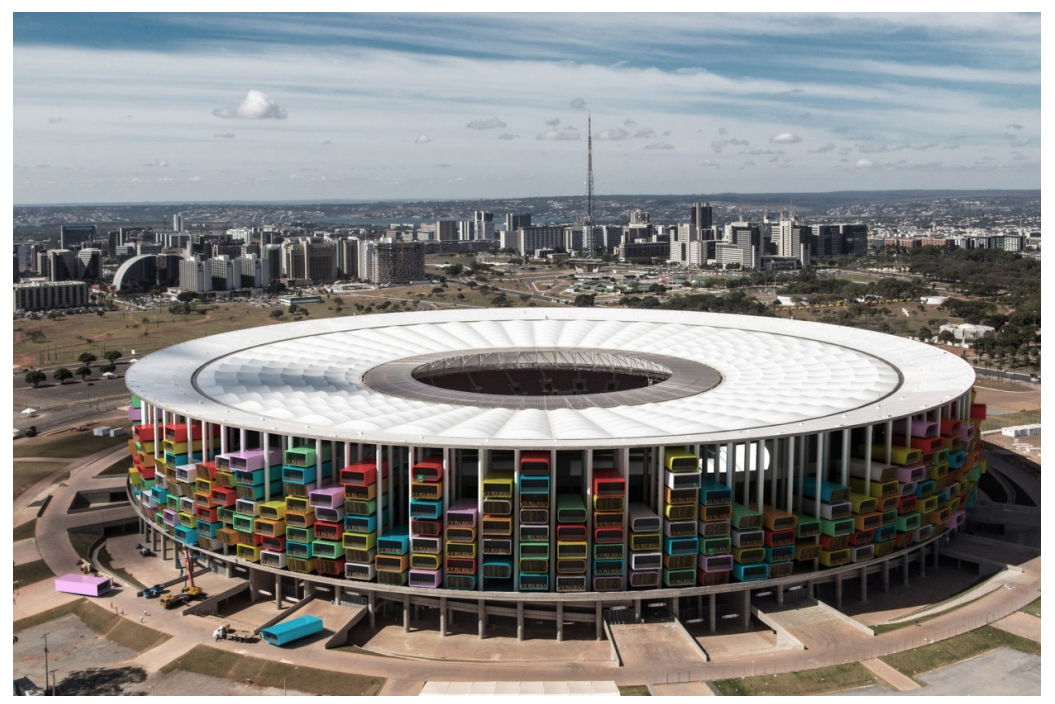

II. 7. Wizualizacja pomysłu Casa Futebol. Fot. T. Faquinii (ArchDaily, 2014) 
utrzymywał jeszcze otaczającą go funkcję. Tworzenie nowych faweli w połączeniu z popadającym w niełaskę stadionem nie wróży świetlanej przyszłości dla tego rozwiązania. Jednak zagospodarowanie części obiektu apartamentowcami, których mieszkańcy spółdzielczym nakładem finansowym wspieraliby stadion, w zamian otrzymując pewne benefity lub ulgi na bilety wraz z możliwością okazyjnego korzystania z niego, jest już potencjalnym rozwiązaniem. Jednak, jak wiadomo, koszty operowania i dopasowywania istniejącego już obiektu są znacznie wyższe niż w przypadku, gdy takie rozwiązanie przewidziano by już na etapie jego projektowania.

\subsection{ST. JAKOB-PARK, BAZYLEA, SZWAJCARIA}

Nowy stadion piłkarski wybudowany w Bazylei według projektu Herzog \& de Meuron zasługuje na szczególną uwagę. Pomimo że został on wzniesiony jeszcze na przełomie XX i XXI wieku, to już wtedy nabrał on hybrydowego charakteru. Jeszcze w 2007 roku był on przebudowywany na potrzeby Euro 2008, aby osiągnąć na czas imprezy pojemność widowni równą 42,5 tysiąca siedzisk. Po zawodach liczbę siedzisk zredukowano do 40 tysięcy. Oprócz stadionu zlokalizowanego niemal 2,5 km na wschód od ścisłego centrum 175-tysięcznego miasta, obiekt posiada dwukondygnacyjny parking na 680 samochodów, dwie restauracje oraz w dodatkowym sektorze galerię handlową składającą się z 32 sklepów rozmieszczonych na trzech kondygnacjach. Ta megastruktura funkcjonuje w sąsiedztwie innych obiektów sportowych, przestrzeni publicznych oraz budynków mieszkalnych i jest świetnie skomunikowana z resztą miasta (il. 8). Konstrukcja St. Jakob-Park jest

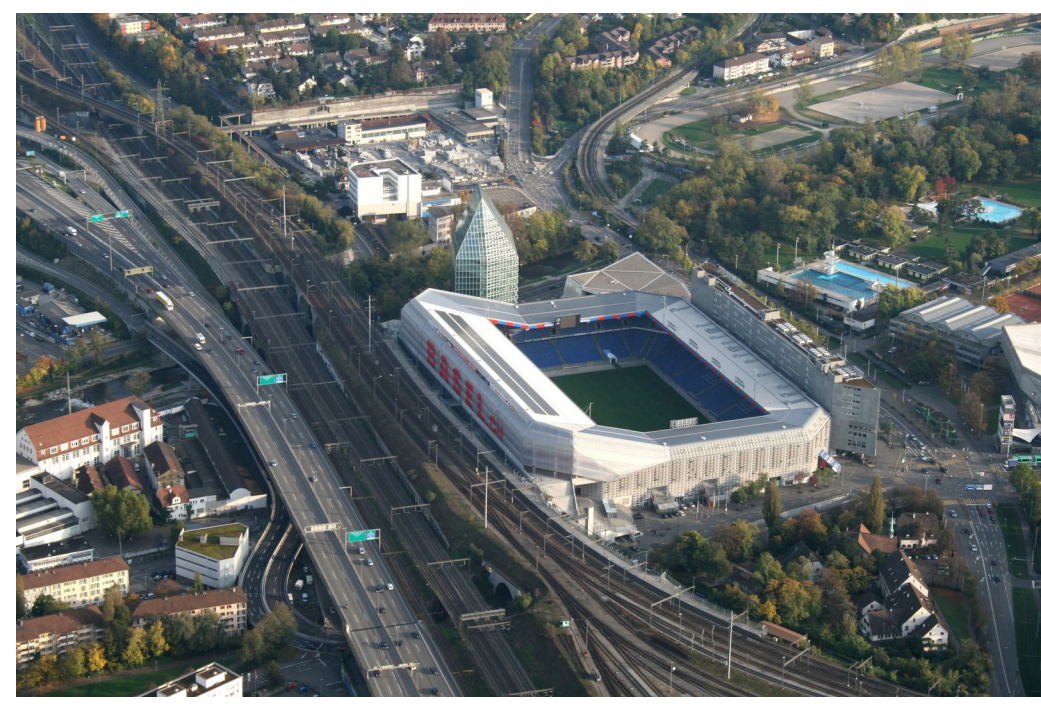

II. 8. St. Jakob-Park z lotu ptaka. Fot. S. Scharr (Janus, 2008) 
połączona z sąsiednim apartamentowcem. Na dachu stadionu zamontowane zostały baterie słoneczne. Dodatkowym ciekawym zabiegiem estetycznym nawiązującym do interakcji informacyjnej ze społeczeństwem jest elewacja, która w zależności od drużyny rozgrywającej mecz jest podświetlona odpowiednim kolorem. Obiekt został nagrodzony najwyższą oceną przyznawaną przez UEFA w postaci czterech gwiazdek dla stadionów czwartej kategorii (najwyższej). W momencie jego wznoszenia w latach 1998-2001 koszt wyniósł około $135 \mathrm{~m} / \mathrm{n}$ dolarów (Janus, 2008).

\subsection{PROJEKTY MEGASTRUKTUR}

Wizje i fantastyczne pomysły futurystycznych wielkich konstrukcji można podziwiać w corocznym prestiżowym konkursie Skyscraper Competition organizowanym przez magazyn „eVolo”. Uczestnicy w oparciu o aspekty postępu technologicznego, rozwoju zrównoważonego i innowacyjnego projektowania przedstawiają megastruktury wybiegające w przyszłość, jednak, przy odpowiednim budżecie, możliwe do zrealizowania. Pomysły od wielkich zielonych farm wieżowców, przez samo wznoszące się konstrukcje po obiekty umożliwiające ich wykonanie na orbicie okołoziemskiej. Obecnie megastruktury są faktem i aspektem, którego rozwijająca się cywilizacja ludzka będzie potrzebowała do osiągania coraz wyższego poziomu życia, wiedzy i rozwoju (Berbesz, 2012).

Tematyka megastruktury hybrydowej związanej z obiektem widowiskowym była inspiracją dla autorów w ich pracy magisterskiej pod tytułem Cinema Architecture - multimedialne centrum przyszłości wykonanej pod opieką profesora Wacława Celadyna w Instytucie Projektowania Budowlanego Wydziału Architektury Politechniki Krakowskiej. Koncepcja zakładała realizację obiektu megastruktury o charakterze hybrydowym łączącym funkcję przestrzeni widowiskowej, mieszkalnej oraz parkingowej (il. 9-11). Co najważniejsze, wizja zakładała koncepcję „zawinięcia” ciągu przestrzennego osiedla mieszkalnego wraz z parkingiem w postaci podwójnej helisy wokół obiektu użyteczności publicznej. Wyłania to wizję obrazu góry usłanej domami z wewnętrznym rdzeniem. W zewnętrznej konstrukcji oprócz mieszkań przewidziano też przestrzeń pod dowolną aranżację, w postaci drobnych sklepów, usług, biur czy tarasów zielonych. Wewnętrzną halę zaprojektowano w oparciu o nowiny technologiczne związane w przyszłości z pokazami holograficznymi, technologią augmented reality i e-sportem. Połączenie kilku funkcji w jednej wielkiej konstrukcji miało za cel zwiększenie użyteczności i opłacalności wznoszenia obiektu. 


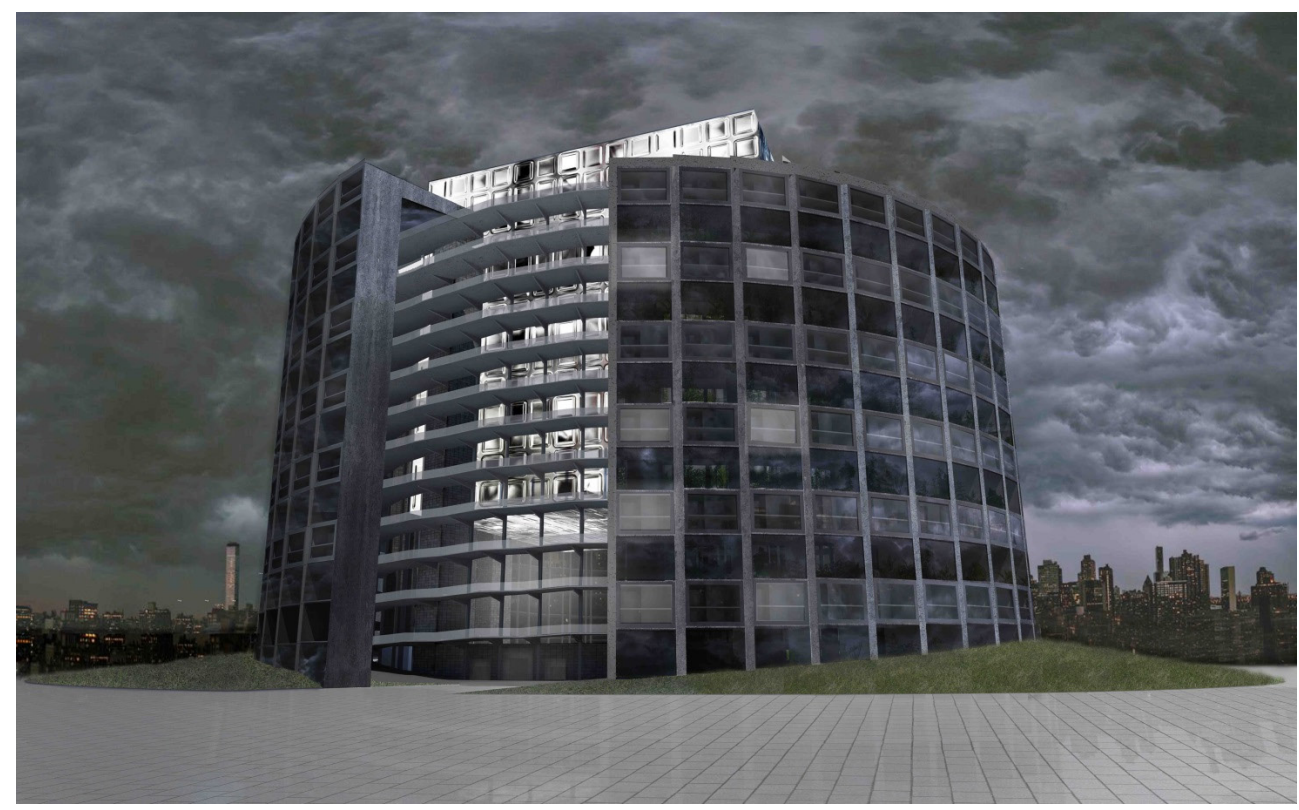

II. 9. Wizualizacja koncepcji hybrydowej megastruktury kina holograficznego. Oprac. własne

\section{SCHEMATY DZIALANIA SPIRAL PARKINGOWYCH OPLATAJĄCYCH BUDYNEK}

PION KOMUNIKACYJNY GOŚC

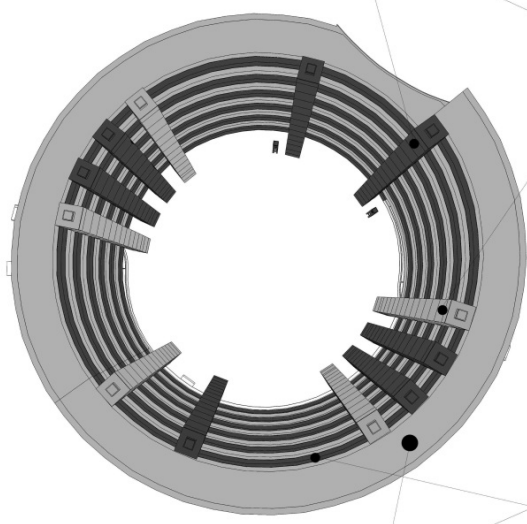

SPIRALA PARKINGOWA MIESZKAŃCÓW
PION KOMUNIKACYJNY MIESZKAŃCÓW

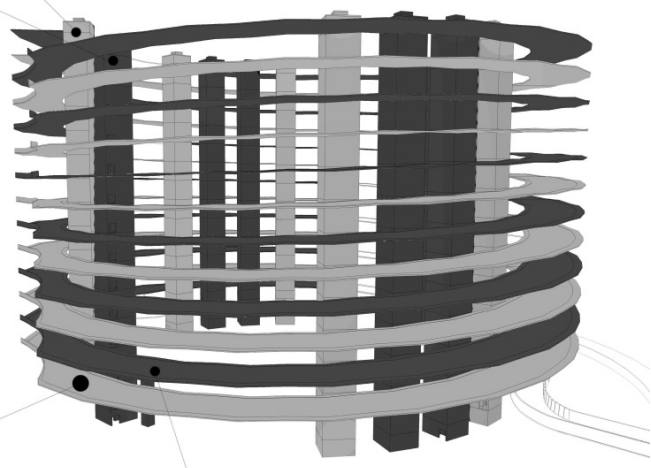

SPIRALA PARKINGOWA GOŚC

II. 10. Schemat działania teoretycznych spiral parkingowych oplatających budynek - megastrukturę.

Oprac. własne 


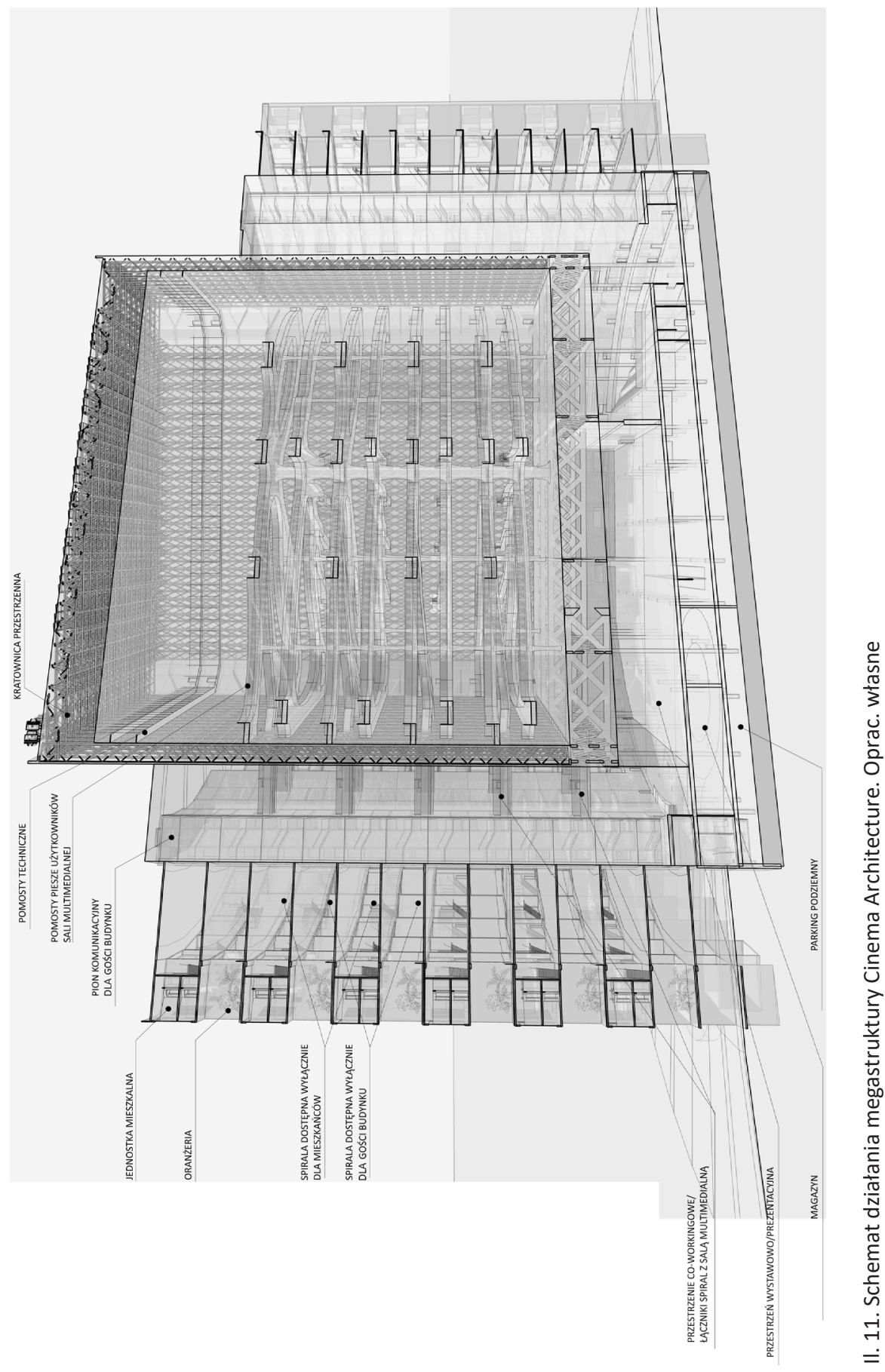




\section{PODSUMOWANIE}

Analizując problematykę dużych obiektów, łatwo można zauważyć, że problemem jest okazjonalność i sezonowość ich użytkowania. Wznoszenie tak ogromnych budowli jak stadiony czy inne hale widowiskowe o charakterze kulturalnym lub sportowym wymaga uzasadnienia w liczbie populacji z nich korzystającej. Późniejsze próby ich zagospodarowania stają się wyzwaniem i zawsze wiążą się z generowaniem stałych kosztów. Dodatkowo wysokie koszty wynajęcia tego typu obiektów wielkopowierzchniowych zawężają grono potencjalnych odbiorców oraz częstotliwość ich użytkowania w celu organizowania zdarzeń mających generować przychód. Brak stałego najemcy sprawia, że budynek taki jak stadion ulegał będzie stopniowemu niszczeniu, tak jak w przypadku stadionów w Brazylii, gdzie sztucznie napędzany popyt na budowę wielkogabarytowych boisk piłkarskich sprawił, że władze kraju zdecydowały się wydać na ich budowę pieniądze otrzymane na ten cel od FIFA bez analizy możliwości uzyskania jakichkolwiek zysków z ich budowy.

Problem ten nie miałby miejsca, gdyby filozofia projektowania megastruktur hybrydowych była wdrażana już na etapie projektowania wielkogabarytowych aren sportowych. Oczywistym jest, że w przypadku budowy stadionów dla znanych klubów piłkarskich w dużych metropoliach zagrożenie brakiem zwrotu kosztów inwestycji jest znikome. Jak pokazuje jednak chociażby przykład St. Jakob-Park w Bazylei, obiekt, który od początku projektowany był jako megastruktura hybrydowa, nawet gdy posiada jedną, dominującą funkcję otoczoną funkcjami pomniejszymi, dodatkowymi, jest w rezultacie znacznie bardziej opłacalny w budowie, generuje regularne zyski ze znacznie większej liczby źródeł.

W przyszłości niezbędne będzie projektowanie budynków, które łączyć w sobie będą wszechstronność funkcji. Powodowane jest to w znacznej mierze przeludnieniem naszej planety i koniecznością oszczędności miejsca i dbałości o naturalny ekosystem. Być może pomocne w przyszłości będzie traktowanie miasta w kategoriach szeroko rozumianego krajobrazu, ze znaczącą szansą na poszerzenie jego tradycyjnej funkcjonalności i znalezienie nowych sposobów projektowania miast (Nyka, 2006). W tym właśnie aspekcie swoje zastosowanie znajdują budynki hybrydowe, oferujące połączenie funkcji mieszkalnej, usługowo-biurowej, handlowej oraz kulturalnej, stając się alternatywą dla powstających obiektów wielkogabarytowych, pochłaniających miliardy dolarów i popadających w ruinę na skutek całkowitego braku elastyczności i różnorodności ich wykorzystania. 


\section{BIBLIOGRAFIA}

ArchDaily, (2014). Markthal Rotterdam/MVRDV. Pobrane z: https://www.archdaily. com/553933/markthal-rotterdam-mvrdv (dostęp: 20.03.2021).

Berbesz, A. (2012). Zespoły Hybrydowe jako próba stworzenia integralnych i multifunkcjonalnych struktur miejskich. Reanimacja czy dewaluacja urbanistyki XX/XXI wieku. Czasopismo Techniczne, 1-A, 63-71.

Burazor, M. (2012). Specific Aspects of Sustainability in the Design of Hybrid Buildings. W: Green Design Conference (s. 2-3). University of Sarajevo, Faculty of Architecture, Bosnia and Herzegovina.

Equipo PARQ. (2014). “Casa Futebol” Proposes a Different Olympic Legacy For Brazil's Stadiums. Pobrane z: https://www.archdaily.com/526191/casa-futebol-proposes-a-differentolympic-legacy-for-brazil-s-stadiums (dostęp: 06.03.2021).

Felisberto das Neves, A.S. (2012). Residential Hybrid Buildings - Different temporalities in city's life. Lisbona: Instituto Superior Tecnico, Universidade Tecnica de Lisbona.

Gringhuis, R., Wiesner, T. (2014). An exploration into the qualities of a true Hybrid Building. Architecture \&Dwelling Graduation Studio, 2013-2014.

Gyurkovich, M. (2013). Hybrydowe przestrzenie kultury we współczesnym mieście europejskim. Kraków: Wydawnictwo PK.

Gyurkovich, M. (2017). Adaptacje zabytkowych struktur dla nowych potrzeb - część 1 wybrane przykłady z Madrytu. Wiadomości Konserwatorskie, 50, 30-43.

Gyurkovich, M. (red.). (2016). Hybrid urban structures. Kraków: Wydawnictwo PK.

Janus, M. (2008). St. Jakob Park. Pobrane z: http://stadiony.net/publikacje/opisy/st_jakob_park (dostęp: 22.03.2021).

Koolhaas, R. (1994). Delinous New York, A Retroactive Manifesto for Manhattan. New York: The Monacelli Press, Inc.

Manfred, T. (2015). Brazil's \$3 billion World Cup stadiums are becoming white elephants a year later. Pobrane z: http://www.businessinsider.com/brazil-world-cup-stadiums-one-yearlater-2015-5?IR=T (dostęp: 06.03.2021).

NBC NEWS. (2014). Brazil's World Cup Stadiums, Re-imagined as Housing Units. Pobrane z: https://www.nbcnews.com/storyline/world-cup/brazils-world-cup-stadiums-reimagined-housing-units-n159151 (dostęp: 06.03.2021).

Nyka, L. (2006). Od architektury cyrkulacji do urbanistycznych krajobrazów. Gdańsk: Wydawnictwo Politechniki Gdańskiej.

Palej, M. (2010). Hybrydy - Nowe Elementy w Strukturze Miast. Czasopismo Techniczne, 6-A, 57-64.

Szpakowska, E. (2010). XXL. Czasopismo Techniczne, 7-A2, 371-375. 
The Guardian. (2015). The Pontiac Silverdome: from dream arena to symbol of American Decay.

Pobrane z: https://www.theguardian.com/sport/2017/dec/01/pontiac-silverdomedemolition-detroit-lions (dostęp: 07.03.2021).

https://en.wikipedia.org/wiki/Megastructure (dostęp: 20.03.2021)

https://en.wikipedia.org/wiki/Pontiac_Silverdome\#cite_note-47 (dostęp: 07.03.2021)

https://en.wikipedia.org/wiki/St._Jakob-Park (dostęp: 22.03.2021)

http://encyklopediafantastyki.pl/index.php?title=Megastruktura (dostęp: 20.03.2021)

http://www.bryla.pl/bryla/56,85301,16476879,_opuszczone_stadiony_wyschniete_baseny_

Ateny_10_lat.html (dostęp: 06.03.2021)

http://www.stadiumguide.com/stjakobpark/ (dostęp: 22.03.2021) 